\title{
Editorial
}

\section{Raça e desempenho atlético}

\author{
Paulo Farinatti, Jean-Louis Peytavin
}

Quando o francês Christophe Lemaître correu os 100 metros rasos em menos de 10 segundos pela primeira vez em 2010 (9'98"), o mito da superioridade negra em corridas de velocidade foi questionado. Rapidamente, apareceram pesquisas mostrando que Lemaitre possuiria genes idênticos aos de Usain Bolt e que, fisicamente, poderia ser assimilado a um corredor senegalês pelo comprimento dos membros inferiores. Mas todas essas comparaçóes revelaram-se irrelevantes: os famosos genes que se exprimiam em Usain Bolt e outros velocistas existiriam também em corredores quenianos de fundo. Além disso, comparar Lemaître a um senegalês soa pelo menos estranho, já que nunca um corredor daquele país alcançou marcas inferiores a 10 segundos. Temos que voltar ao fato fundamental: a superioridade negra não é uma questão de raça, mas de grupos bem específicos, compostos basicamente de Afro-Americanos e Jamaicanos. A superioridade inata seria menos importante que fatores extrínsecos, como investimento, seleçáo e treinamento.

Voltando à África, a mesma lógica usualmente aplicada aos velocistas poderia ser aventada a corredores de fundo e meio-fundo do Quênia ou Etiópia, os quais monopolizam recordes e lideram campeonatos há 30 anos? Existiria uma superioridade de negros oriundos do Leste da África? Nesse sentido, dentre os artigos incluídos nesta edição da RBFEx, comentamos o interessante estudo elaborado por José Augusto Rodrigues dos Santos e Tânia Amorim, da Universidade do
Porto (Portugal). Os autores produziram uma revisão exaustiva sobre o assunto, na qual analisam variáveis biológicas (genéticas, antropométricas, fisiológicas, morfológicas) e sócio-ambientais, como a nutrição e o estilo de vida, quanto à sua influência sobre os resultados desses corredores.

É interessante notar que, no estado atual do conhecimento, os fatores que melhor explicariam o sucesso dos corredores africanos de fundo, novamente recairiam sobre particularidades relacionadas ao treinamento (recuperação e sono, esforços de intensidade maior que concorrentes caucasianos etc.) e aspectos psicológicos, como a vontade de ganhar e certa aura de invencibilidade, que serviria como reforço positivo.

Desvaloriza-se a questão genética como determinante de resultados atléticos, o que, certamente, será objeto de estudos cada vez mais aprofundados, no que tange ao mapeamento de características que favorecem certos tipos de desempenho, mas também ao valor relativo dessa informação no campo da aplicação prática. Afinal, em que pesem aspectos éticos a serem discutidos, até que ponto o aspecto genético poderia ser manipulado e, principalmente, em que medida isso valeria a pena, dada a influência de outros fatores para produzir rendimento de alto nível. Pode-se fazer uma analogia com o aforismo atribuído a Winston Churchill, "a sorte não existe, é um conjunto de pequenos detalhes". Isso parece se aplicar ao desporto de elite - ter a sorte de nascer com os "genes certos" seria suficiente para produzir um atleta? 